\title{
УДК 636:616.98:578.824.11:616-036.22
}

DOI: $10.31073 /$ vet_biotech39-09

ПОЛУПАН І.М., канд. вет. наук, e-mail: vetmedic@ ukr.net,

РУДОЙ О.В., канд. вет. наук, е-mail: rudspass@gmail.com,

ЛОЖкІНА О.В., канд. вет. наук, e-mail: pat.lab@i.ua,

ПАВЛУНЬКО В.Г., e-mail: vovatet@ukr.net,

КУПНЕВСЬКА М.В., e-mail: masiamba@ukr.net,

ТЕПЛИХ Н.I., e-mail: pat.lab@i.ua,

КРАВЧЕНКО А.Л., e-mail: vetmedic@ukr.net

Державний науково-дослідний інститут з лабораторної діагностики та ветеринарно-санітарної експертизи

ГІБАЛЮК Ю.О., e-mail: y.hibaliuk@dpss.gov.ua

Державна служба України з питань безпечності харчових продуктів та захисту споживачів

\section{ОЦНКА ЕФЕКТИВНОСТІ ПЕРОРАЛЬНОЇ ІМУНІЗАЦЇ̈ ДИКИХ М'ЯСОЇДНИХ ТВАРИН ПРОТИ СКАЗУ (2018-2020 рр.)}

В статті представлені матеріали щзодо аналізу ефективності кампаній з пероральної вакцинації диких м'ясоїдних тварин проти сказу, які були проведені в Украӥні в 2018-2020 рр. Оцінка ефективності кампаній з пероральної вакцинації диких м'ясоїдних проти сказу в 2018-2020 роках виявила ефективність цього заходу, однак для досягнення належного результату необхідним є проведення кампаній двічі на рік - весною та восени.

Дослідження показали тенденцію до зменшення превалентності сказу тварин в Україні протягом 2018-2020 років (в 2019 рочі на 25,0\% порівняно з 2018 роком; в 2020 рочі на 11,1\% порівняно з 2019 роком). Виявлено біомаркер тетрациклін в зубах диких м'ясоїдних тварин у 14646 зразках із 31001 досліджених, щзо становило 47,24\%. Серологічними дослідженнями виявлено 37,7\% позитивних тварин після кампанії 2018 року; 24,3\% позитивних сироваток після кампанї 2019 року та 18,6\% після кампанії 2020 року.

Ключові слова: сказ, епізоотична ситуачія, пероральна вакцинація, дикі м'ясоїдні тварини, біомаркер тетрациклін, антирабічні антитіла.

Вступ. Сказ - особливо небезпечна вірусна інфекція, основним джерелом якої в Європі, у тому числі й в Україні, є дикі м'ясоїдні тварини, зокрема червона лисиця (Vulpes vulpes). За оцінкою ВООЗ, сказ включений до п’яти найнебезпечніших зоонозів [1], а відсутність засобів лікування формує соціальне значення цієї інфекції.

Постійне неблагополуччя території України щодо сказу тварин вимагає впровадження ефективних протиепізоотичних заходів, серед яких основне місце відводиться пероральній імунізації диких м'ясоїдних тварин проти сказу, 
ефективність якої доведена як в експериментальних, так і в польових умовах [2-6].

В Україні кампанії з пероральної імунізації лисиць проти сказу почали впроваджувати в польових умовах наприкінці XX століття [7]. 32006 року розпочалися широкомасштабні кампанії, а протягом 2006-2014 рр. постійно здійснювали пероральну імунізацію лисиць проти сказу в східних областях (Донецькій, Харківській, Сумській, Полтавській та Луганській).

Крім того, з 2012 року пероральна вакцинація лисиць проти сказу проводилася в західних областях України (на кордоні 3 Польщею та Угорщиною) [7]. Кампанії проводилися з поступовим збільшенням території

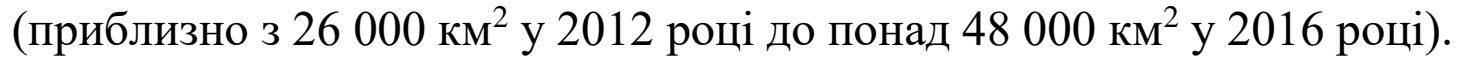

32016 року для розповсюдження антирабічної вакцини впроваджено автоматизовану систему запису географічних координат дистрибуції принад 3 вакциною. Для цього, електронний метроном, який підключений до глобальної системи позиціонування (GPS CDU-4), регулював частоту скидання вакцини, враховуючи швидкість літака, тим самим забезпечуючи велику ймовірність однорідності розподілу вакцини [8].

Ефективність та доцільність впровадження в практику пероральної вакцинації диких м'ясоїдних проти сказу в Україні автоматизованої системи запису географічних координат дистрибуції принад з вакциною була врахована в новій редакції Методичних рекомендацій «Планування, організація та проведення пероральної імунізації м'ясоїдних тварин проти сказу», які були затверджені 24 квітня 2018 р. Протоколом № 1 Науково-методичної ради Держпродспоживслужби України.

З 2018 року в Україні розпочато проведення широкомасштабних кампаній 3 пероральної імунізації диких м'ясоїдних тварин проти сказу. Загальна площа

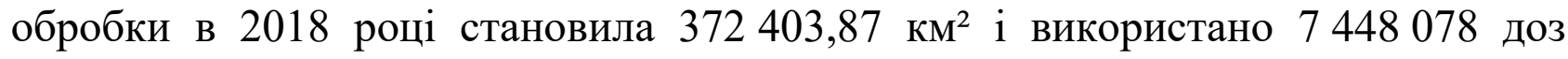
вакцини. Для цього використовували живу антирабічну вакцину «Орісвак» та рекомбінантну вакцину «Броварабіс V-RG», що виробляються TOB «Укрветпромпостач». В 2019 році проведено кампанію з пероральної імунізації диких м'ясоїдних тварин на площі 465 230,47 км², де використано 11630764 доз антирабічної вакцини «Орісвак». В 2020 році проведено кампанію 3 пероральної імунізації диких м'ясоїдних тварин на площі 406 298,74 км², де використано 10157470 доз антирабічної вакцини «Орісвак».

Однак, кампанії з пероральної вакцинації диких м'ясоїдних проти сказу в 2018-2020 рр. проводилися лише одноразово в рік (восени - вересень-грудень), хоча оптимальна модель цього протиепізоотичного заходу є дворазова, яку проводять весною і восени. Така модель пероральної вакцинації диких тварин проти сказу використовувалася в усіх європейських програмах та показала 
свою ефективність, незалежно від щільності популяції лисиць, та призвела до ерадикації сказу в багатьох країнах $[2,5,9]$.

Контроль ефективності пероральної вакцинації диких м'ясоїдних тварин проти сказу здійснюється завдяки активному спостереженню (моніторингу):

1. епізоотологічний нагляд за зоною вакцинації;

2. дослідження зубів лисиць на наявність біомаркеру - тетрацикліну;

3. оцінка сироваток крові лисиць на наявність антитіл до вірусу сказу.

Враховуючи вищезгадане, метою роботи було здійснення оцінки ефективності кампаній пероральної вакцинації диких м'ясоїдних тварин проти сказу, що проводилися в Україні в 2018-2020 рр.

Матеріали і методи досліджень. Патологічний матеріал (мозок) у відстріляних тварин досліджувався в регіональних лабораторіях ветеринарної медицини методом флуоресціюючих антитіл (FAT) [10].

Дослідження зубів і сироваток крові кампаній 2018-2019 рр. проводилися на базі науково-дослідного патоморфологічного та науково-дослідного вірусологічного відділів ДНДІЛДВСЕ (м. Київ) та Регіональної державної лабораторії Держпродспоживслужби в Полтавській області (м. Полтава). Аналіз ефективності кампанії з пероральної вакцинації диких м'ясоїдних проти сказу в 2020 році здійснено в ДНДІЛДВСЕ (м. Київ).

Наявність біомаркеру визначали дослідженням гістологічних зрізів в ультрафіолетовому спектрі під люмінесцентним мікроскопом Micros Austria MC 300 (Австрія). Матеріалом для дослідження були гістологічні зрізи ікол, які були відібрані від відстріляних тварин у мисливських угіддях не менше ніж через 30 днів після завершення кампанії 3 пероральної вакцинації диких м'ясоїдних проти сказу. Спили робили за допомогою прецензійної пилки ISOMET та отримували зрізи товщиною від 0,2 до 0,6 мм (рис. 1). Зразок містив пульпарну порожнину, дентин, цемент та деякі шматочки кістки.

Тетрациклінові лінії виглядали, як жовті лінії на блакитному фоні. Надалі, характеризували різні елементи: якість зрізу, наявність тетрацикліну, кількість ліній тетрацикліну.

Кількість ліній може бути визначена в дентині тільки у лисиць віком до 1 року. Після цього віку кілька приманок, з’їдених в одній кампанії, дасть одну товщу або тоншу лінію. Виявлення тетрацикліну в цементі дозволяє встановити сезон поїдання приманки та рік. Наявність флуоресценції на всій поверхні зрізу вказує на поїдання приманки за 1-3 місяці до смерті.

При наявності тетрацикліну в гістологічному зрізі при люмінісценції спостерігали свічення у вигляді жовтувато-зеленого кольору, так звана тетрациклінова мітка (позитивний результат) (рис. 2). При відсутності тетрациклінової мітки - результат негативний. 


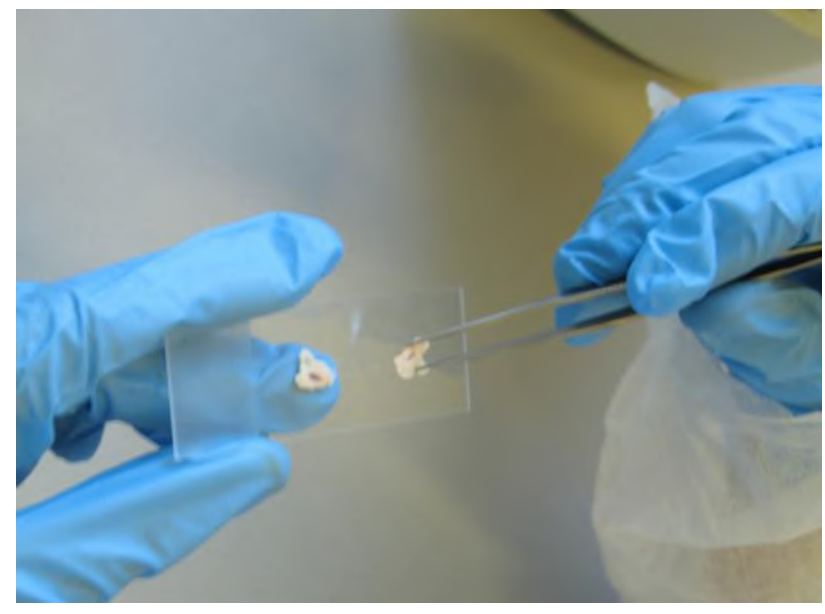

Рис. 1. Спили ікла нижньої щелепи лисиці.

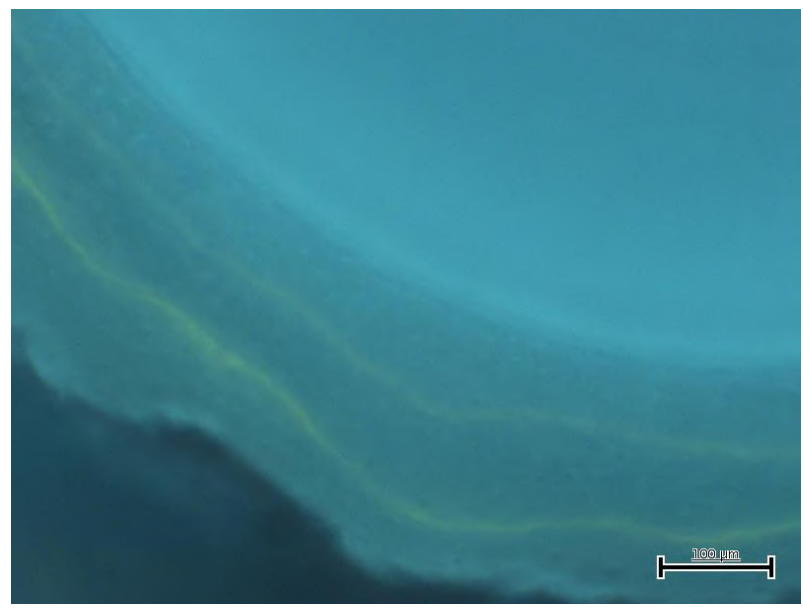

Рис. 2. Лінії тетрацикліну у цементі ікла.

Сироватки на наявність антитіл до вірусу сказу досліджували методом ELISA. Для цього використовували діагностичні набори BioPro Rabies Elisa Ab та Platelia Rabies II BioRad (згідно інструкції виробника). У разі використання тест-системи BioPro Rabies Elisa Ab позитивними вважалися сироватки 3 пороговим значенням $\geq 70 \%$ блокування. Сироватки крові лисиць при дослідженні тест-системою Platelia Rabies II BioRad вважалися позитивними за наявності сероконверсії $\geq 0,125 \mathrm{MO} / \mathrm{cm}^{3}$.

Результати досліджень та їх обговорення. Відповідно до Методичних рекомендацій «Планування, організація та проведення пероральної імунізації м'ясоїдних тварин проти сказу» контроль ефективності кампаній з пероральної вакцинації диких м'ясоїдних тварин проти сказу проводиться шляхом:

1. Епізоотичного нагляду за зоною здійснення вакцинації (пасивний моніторинг - дослідження методом флуоресціюючих антитіл зразків мозку тварин, що підозрілі в захворюванні, та активний моніторинг - дослідження зразків мозку лисиць, що були відстріляні в зоні проведення пероральної вакцинації);

2. Дослідження зубів лисиць на наявність біомаркеру - тетрацикліну;

3. Дослідження сироваток крові лисиць на наявність антитіл до вірусу сказу.

Відстріл лисиць проводять не менше ніж через 30 днів після завершення кампанії з пероральної вакцинації в кількості 2-4 лисиці/100 км² території. Перед надсиланням матеріалу для дослідження головний мозок лисиць тестується на наявність антигену вірусу сказу методом флуоресціюючих антитіл (FAT). У разі виявлення антигену вірусу сказу в головному мозку, сироватки крові та щелепи на дослідження не направлялися. 


\section{Епізоотичний нагляд.}

Протягом 2018-2020 pp. епізоотична ситуація щодо сказу в Україні була напруженою із коливанням кількості випадків в різних областях (табл. 1).

Таблиия 1

Інформація з діагностики сказу тварин в Україні в 2018-2020 рр.

\begin{tabular}{|c|c|c|c|c|c|c|}
\hline \multirow{3}{*}{ Регіони } & \multicolumn{6}{|c|}{ Досліджень } \\
\hline & \multicolumn{2}{|c|}{2018} & \multicolumn{2}{|c|}{2019} & \multicolumn{2}{|c|}{2020} \\
\hline & Всього & позиТивно & всього & позитивно & всього & ПозиТивно \\
\hline Вінницька & 1770 & 264 & 1962 & 346 & 1696 & 227 \\
\hline Волинська & 707 & 23 & 858 & 20 & 416 & 24 \\
\hline Дніпропетровська & 448 & 86 & 1323 & 26 & 1359 & 23 \\
\hline Донецька & 206 & 59 & 246 & 75 & 476 & 108 \\
\hline Житомирська & 680 & 99 & 968 & 68 & 832 & 52 \\
\hline Закарпатська & 418 & 21 & 367 & 26 & 357 & 16 \\
\hline Запорізька & 320 & 106 & 687 & 114 & 630 & 48 \\
\hline Івано-Франківська & 764 & 23 & 657 & 20 & 759 & 25 \\
\hline Київська & 469 & 50 & 737 & 19 & 600 & 114 \\
\hline Кіровоградська & 415 & 153 & 886 & 64 & 948 & 82 \\
\hline Луганська & 173 & 65 & 472 & 24 & 566 & 35 \\
\hline Львівська & 1084 & 43 & 1524 & 27 & 1117 & 15 \\
\hline Миколаївська & 278 & 59 & 778 & 35 & 710 & 44 \\
\hline Одеська & 233 & 46 & 752 & 37 & 798 & 46 \\
\hline Полтавська & 933 & 43 & 1163 & 20 & 991 & 42 \\
\hline Рівненська & 723 & 52 & 707 & 27 & 499 & 17 \\
\hline Сумська & 276 & 81 & 706 & 19 & 426 & 11 \\
\hline Тернопільська & 423 & 54 & 370 & 27 & 332 & 15 \\
\hline Харківська & 363 & 109 & 666 & 37 & 442 & 30 \\
\hline Херсонська & 603 & 46 & 922 & 12 & 705 & 15 \\
\hline Хмельницька & 967 & 213 & 1296 & 122 & 1032 & 62 \\
\hline Черкаська & 622 & 116 & 1011 & 231 & 890 & 197 \\
\hline Чернівецька & 226 & 6 & 341 & 25 & 340 & 10 \\
\hline Чернігівська & 577 & 89 & 1604 & 12 & 673 & 4 \\
\hline м. Київ & 182 & 10 & 89 & 4 & 72 & 15 \\
\hline Всього & 13860 & 1916 & 21092 & 1437 & 17666 & 1277 \\
\hline
\end{tabular}

Так, зменшення кількості випадків сказу протягом 2018-2020 pp. відмічено в Дніпропетровській, Житомирській, Запорізькій, Львівській, Рівненській, Сумській, Тернопільській, Харківській, Херсонській, Хмельницькій та Чернігівській областях. Однак, в Донецькій, Київській та Черкаській областях відмічено ріст захворюваності тварин на сказ, не зважаючи на здійснені кампанії з пероральної вакцинації диких м'ясоїдних проти сказу. В 
решті областей України не виявлено чіткої тенденції до зміни напруженості епізоотичної ситуації зі сказу протягом 2018-2020 рр.

Загалом виявлена тенденція до зменшення превалентності сказу тварин в Україні протягом трьох років. В 2019 році кількість лабораторно підтверджених випадків сказу була меншою на 479 випадків, або на 25,0 \% порівняно 32018 роком; в 2020 році на 160 випадків менше, або на 11,1 \% порівняно 32019 роком. Зменшення кількості випадків сказу на території, на якій проводиться пероральна вакцинація диких м’ясоїдних тварин проти сказу, є одним 3 критеріїв позитивного впливу цих антирабічних протиепізоотичних заходів, однак потребує додаткових досліджень спалахів сказу серед тварин 3 використанням інструментів геоінформаційних систем та результатів молекулярно-генетичних характеристик ізолятів вірусу сказу.

Біомаркер - тетрациклін.

Дослідження 3 виявлення біомаркеру тетрацикліну в зубах диких м’ясоїдних тварин проводили методом флуоресцентної мікроскопії під люмінісцентним мікроскопом в ультрафіолетовому спектрі. У зрізах зубів позитивних зразків спостерігали свічення ліній тетрацикліну в дентині, цементі та фрагментах кісток навколо зуба (в усіх ділянках одночасно або лише в одній iз ділянок). Всього проведено 31001 досліджень, з яких позитивних результатів на наявність біомаркеру тетрацикліну в зубах диких м’ясоїдних - 14646 (табл. 2).

Таблиця 2

Результати досліджень в розрізі областей за 2018-2020 рр.

\begin{tabular}{|c|c|c|c|c|c|c|c|c|c|c|}
\hline \multirow[b]{2}{*}{ Область } & \multirow[b]{2}{*}{ Вік лисиць } & \multicolumn{3}{|c|}{2018} & \multicolumn{3}{|c|}{2019} & \multicolumn{3}{|c|}{2020} \\
\hline & & 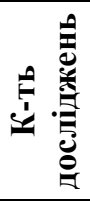 & 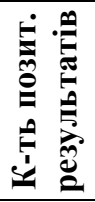 & 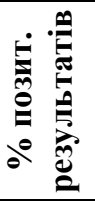 & 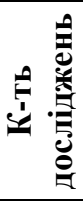 & 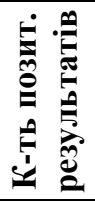 & 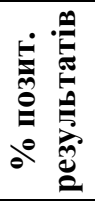 & 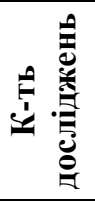 & 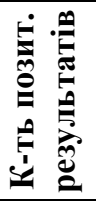 & 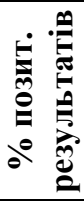 \\
\hline 1 & 2 & 3 & 4 & 5 & 6 & 7 & 8 & 9 & 10 & 11 \\
\hline \multirow{2}{*}{ Вінницька } & Лисиця молода 0-1 & 323 & 86 & 26,6 & 226 & 74 & 32,7 & 59 & 33 & 55,9 \\
\hline & Старше 1 року & 397 & 106 & 26,7 & 634 & 230 & 36,3 & 425 & 209 & 49,2 \\
\hline \multirow{2}{*}{ Волинська } & Лисиця молода 0-1 & - & - & - & 458 & 39 & 24,7 & - & - & - \\
\hline & Старше 1 року & - & - & - & 532 & 290 & 54,5 & - & - & - \\
\hline \multirow{2}{*}{ Донецька } & Лисиця молода 0-1 & 49 & 32 & 65,3 & 35 & 21 & 60,0 & 23 & 9 & 39,1 \\
\hline & Старше 1 року & 172 & 117 & 68,0 & 193 & 115 & 59,6 & 203 & 74 & 36,5 \\
\hline \multirow{2}{*}{$\begin{array}{l}\text { Дніпро } \\
\text { петровська }\end{array}$} & Лисиця молода 0-1 & 203 & 138 & 68,0 & 220 & 123 & 55,9 & 188 & 97 & 51,6 \\
\hline & Старше 1 року & 564 & 404 & 71,6 & 840 & 521 & 66,8 & 919 & 394 & 42,9 \\
\hline \multirow{2}{*}{ Житомирська } & Лисиця молода 0-1 & 139 & 64 & 46,0 & 83 & 30 & 36,1 & 94 & 35 & 37,2 \\
\hline & Старше 1 року & 353 & 121 & 34,3 & 422 & 192 & 50,5 & 421 & 187 & 44,4 \\
\hline \multirow{2}{*}{ Закарпатська } & Лисиця молода 0-1 & 6 & 1 & 16,6 & 36 & 16 & 44,4 & 29 & 15 & 51,7 \\
\hline & Старше 1 року & 8 & 6 & 75,0 & 257 & 122 & 47,5 & 190 & 88 & 46,3 \\
\hline
\end{tabular}


Продовження таблиці 2

\begin{tabular}{|c|c|c|c|c|c|c|c|c|c|c|}
\hline 1 & 2 & 3 & 4 & 5 & 6 & 7 & 8 & 9 & 10 & 11 \\
\hline \multirow{2}{*}{ Запорізька } & Лисиця молода 0-1 & 81 & 56 & 69,1 & 88 & 49 & 55,7 & 61 & 20 & 32,8 \\
\hline & Старше 1 року & 178 & 131 & 73,6 & 250 & 170 & 68,0 & 214 & 76 & 35,5 \\
\hline \multirow{2}{*}{$\begin{array}{l}\text { Івано- } \\
\text { Франківська }\end{array}$} & Лисиця молода $0-1$ & 243 & 62 & 25,5 & 88 & 34 & 38,6 & 63 & 34 & 54,0 \\
\hline & Старше 1 року & 239 & 62 & 25,9 & 418 & 183 & 43,8 & 344 & 157 & 45,6 \\
\hline \multirow{2}{*}{ Київська } & Лисиця молода 0-1 & 107 & 31 & 29,0 & 73 & 35 & 48,0 & 112 & 66 & 58,9 \\
\hline & Старше 1 року & 171 & 28 & 16,4 & 349 & 164 & 47,0 & 322 & 133 & 41,3 \\
\hline \multirow{2}{*}{ Кіровоградська } & Лисиця молода 0-1 & 76 & 43 & 56,6 & 259 & 144 & 55,6 & 100 & 61 & 61,0 \\
\hline & Старше 1 року & 208 & 91 & 43,8 & 595 & 363 & 61,0 & 594 & 228 & 38,4 \\
\hline \multirow{2}{*}{ Луганська } & Лисиця молода 0-1 & 39 & 17 & 43,6 & 101 & 49 & 48,5 & 128 & 41 & 32,0 \\
\hline & Старше 1 року & 195 & 110 & 56,4 & 370 & 246 & 66,5 & 273 & 78 & 28,6 \\
\hline \multirow{2}{*}{ Львівська } & Лисиця молода $0-1$ & 94 & 22 & 23,4 & 134 & 49 & 36,6 & - & 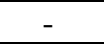 & - \\
\hline & Старше 1 року & 262 & 112 & 42,7 & 521 & 269 & 51,6 & - & - & - \\
\hline \multirow{2}{*}{ Миколаївська } & Лисиця молода 0-1 & 13 & 7 & 53,8 & 130 & 76 & 58,5 & 96 & 58 & 60,4 \\
\hline & Старше 1 року & 68 & 47 & 69,1 & 345 & 188 & 54,5 & 360 & 137 & 38,0 \\
\hline \multirow{2}{*}{ Одеська } & Лисиця молода $0-1$ & 24 & 12 & 50,0 & 137 & 68 & 49,6 & 102 & 61 & 59,8 \\
\hline & Старше 1 року & 38 & 30 & 78,9 & 356 & 177 & 49,8 & 530 & 260 & 49,1 \\
\hline \multirow{2}{*}{ Полтавська } & Лисиця молода $0-1$ & 114 & 31 & 27,2 & 144 & 45 & 31,2 & 121 & 64 & 52,9 \\
\hline & Старше 1 року & 294 & 87 & 29,6 & 664 & 237 & 35,7 & 552 & 216 & 39,1 \\
\hline \multirow{2}{*}{ Рівненська } & Лисиця молода $0-1$ & 154 & 62 & 40,3 & 68 & 21 & 30,9 & 26 & 11 & 42,3 \\
\hline & Старше 1 року & 258 & 70 & 27,1 & 244 & 83 & 34,0 & 241 & 94 & 39,0 \\
\hline \multirow{2}{*}{ Сумська } & Лисиця молода 0-1 & 80 & 54 & 67,5 & 118 & 72 & 61,0 & 44 & 25 & 56,8 \\
\hline & Старше 1 року & 321 & 258 & 80,4 & 476 & 350 & 73,5 & 311 & 149 & 47,9 \\
\hline \multirow{2}{*}{ Тернопільська } & Лисиця молода $0-1$ & 79 & 25 & 31,6 & 45 & 18 & 40,0 & 45 & 14 & 31,1 \\
\hline & Старше 1 року & 155 & 31 & 20,0 & 221 & 135 & 61,1 & 199 & 83 & 41,7 \\
\hline \multirow[b]{2}{*}{ Харківська } & Лисиця молода $0-1$ & 37 & 15 & 40,5 & 85 & 36 & 42,4 & 100 & 44 & 44,0 \\
\hline & Старше 1 року & 160 & 58 & 36,3 & 274 & 162 & 59,1 & 303 & 107 & 35,3 \\
\hline \multirow{2}{*}{ Херсонська } & Лисиця молода 0-1 & 55 & 34 & 61,8 & 122 & 76 & 62,3 & 119 & 67 & 56,3 \\
\hline & Старше 1 року & 244 & 168 & 68,9 & 300 & 207 & 69,0 & 384 & 191 & 49,7 \\
\hline \multirow{2}{*}{ Хмельницька } & Лисиця молода 0-1 & 250 & 70 & 28,0 & 180 & 72 & 40,0 & 108 & 62 & 57,4 \\
\hline & Старше 1 року & 355 & 122 & 34,4 & 520 & 235 & 45,2 & 616 & 277 & 45,0 \\
\hline \multirow{2}{*}{ Черкаська } & Лисиця молода 0-1 & 104 & 75 & 72,1 & 65 & 41 & 63,1 & 46 & 21 & 45,7 \\
\hline & Старше 1 року & 156 & 92 & 59,0 & 231 & 162 & 70,1 & 246 & 67 & 27,2 \\
\hline \multirow{2}{*}{ Чернівецька } & Лисиця молода 0-1 & 55 & 15 & 27,3 & 34 & 4 & 10,5 & 33 & 19 & 57,6 \\
\hline & Старше 1 року & 87 & 16 & 18,4 & 190 & 58 & 30,5 & 176 & 72 & 40,9 \\
\hline \multirow{2}{*}{ Чернігівська } & Лисиця молода 0-1 & 109 & 74 & 67,9 & 323 & 143 & 44,3 & 80 & 44 & 55,0 \\
\hline & Старше 1 року & 358 & 289 & 80,7 & 724 & 409 & 56,5 & 548 & 283 & 51,6 \\
\hline Всього: & & 7675 & 3582 & 46,7 & 13178 & 6603 & 50,1 & 10148 & 4461 & 44,0 \\
\hline
\end{tabular}

Із даних таблиці, відмічаємо зниження у 2020 р. відсотку позитивних результатів (44,0\%) на 2,7\% відносно 2018 р., а в 2019 р. - найвищий показник наявності біомаркеру тетрацикліну в зубах диких м'ясоїдних $(50,1 \%)$ порівняно із 2018 та 2020 pp.

Серологічний моніторинг.

Одним з ключових етапів оцінки ефективності пероральної вакцинації диких м'ясоїдних тварин проти сказу є визначення напруженості антирабічного імунітету. Результати досліджень антирабічної активності сироваток крові диких м'ясоїдних тварин після трьох кампаній пероральної вакцинації представлені в таблиці 3. 
Таблиия 3

Результати досліджень антирабічного імунітету в диких м'ясоїдних тварин після кампаній з пероральної вакцинації в 2018-2020 рр.

\begin{tabular}{|c|c|c|c|c|c|c|c|c|c|}
\hline \multirow[b]{3}{*}{ Область } & \multicolumn{9}{|c|}{ Сироватки крові диких м'ясоїдних тварин } \\
\hline & \multicolumn{3}{|c|}{2018} & \multicolumn{3}{|c|}{2019} & \multicolumn{3}{|c|}{2020} \\
\hline & 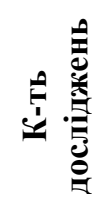 & 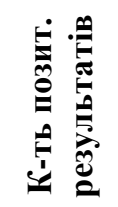 & 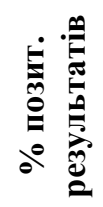 & 兽兽 & 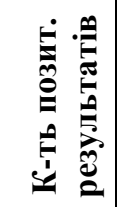 & 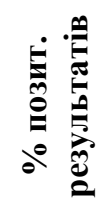 & 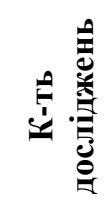 & 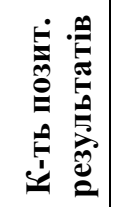 & 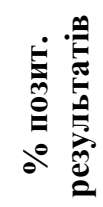 \\
\hline Вінницька & 680 & 133 & 19,3 & 860 & 49 & 5,7 & 490 & 55 & 11,2 \\
\hline Волинська & - & - & - & 400 & 77 & 19,2 & - & - & - \\
\hline Дніпропетровська & 490 & 270 & 55,1 & 204 & 77 & 37,7 & 595 & 114 & 28,4 \\
\hline Донецька & 214 & 96 & 44,8 & 233 & 53 & 22,7 & 226 & 22 & 9,7 \\
\hline Житомирська & 380 & 126 & 33,1 & 334 & 83 & 24,9 & 268 & 91 & 34,0 \\
\hline Закарпатська & 12 & 2 & 40,0 & 22 & 5 & 22,7 & 60 & 13 & 21,7 \\
\hline Запорізька & 245 & 132 & 53,8 & 347 & 126 & 36,3 & 269 & 80 & 30,0 \\
\hline Івано-Франківська & 443 & 162 & 36,6 & 474 & 97 & 20,5 & 407 & 51 & 12,5 \\
\hline Київська & 56 & 12 & 21,4 & 113 & 27 & 23,8 & 257 & 16 & 6,2 \\
\hline Кіровоградська & 286 & 121 & 42,3 & 301 & 98 & 32,5 & 678 & 153 & 22,6 \\
\hline Луганська & 235 & 105 & 44,6 & 309 & 73 & 23,6 & 401 & 41 & 10,2 \\
\hline Львівська & 248 & 109 & 21,5 & 531 & 114 & 25,2 & - & - & - \\
\hline Миколаївська & 81 & 43 & 53,1 & 481 & 66 & 13,7 & 456 & 21 & 4,6 \\
\hline Одеська & 63 & 29 & 46,0 & 406 & 156 & 38,4 & 658 & 153 & 23,1 \\
\hline Полтавська & 380 & 88 & 23,2 & 602 & 112 & 18,6 & 670 & 177 & 26,4 \\
\hline Рівненська & 187 & 40 & 21,4 & 242 & 65 & 26,8 & 206 & 44 & 21,4 \\
\hline Сумська & 88 & 50 & 56,8 & 200 & 95 & 47,5 & 327 & 96 & 29,4 \\
\hline Тернопільська & 70 & 19 & 27,1 & 137 & 28 & 20,5 & 155 & 7 & 4,5 \\
\hline Харківська & 198 & 79 & 39,8 & 364 & 118 & 32,4 & 410 & 58 & 14,2 \\
\hline Херсонська & 278 & 142 & 51,1 & 387 & 117 & 30,2 & 425 & 155 & 36,5 \\
\hline Хмельницька & 350 & 97 & 27,7 & 648 & 149 & 23,0 & 799 & 66 & 8,3 \\
\hline Черкаська & 228 & 69 & 30,2 & 198 & 44 & 22,2 & 143 & 14 & 9,8 \\
\hline Чернівецька & 101 & 24 & 23,7 & 193 & 20 & 10,3 & 209 & 39 & 18,6 \\
\hline Чернігівська & 214 & 133 & 62,2 & 918 & 320 & 34,8 & 650 & 166 & 25,5 \\
\hline Всього & 5527 & 2081 & 37,7 & 8904 & 2169 & 24,3 & 8759 & 1632 & 18,6 \\
\hline
\end{tabular}

Протягом трьох років (2018-2020 рр.) було лабораторно досліджено 23190 сироваток крові диких м'ясоїдних тварин на наявність антитіл до вірусу сказу. Однак, здійснена оцінка ефективності кампаній з пероральної вакцинації диких м'ясоїдних проти сказу на території України показала неоднозначні результати. Так, в 2018 році було виявлено 37,7\% позитивних тварин за серологічними дослідженнями. Однак, в 2019 і 2020 роках відсоток позитивних сироваток крові був нижчий: 24,3\% та 18,6\% відповідно. Поясненням цієї ситуації може бути певна відмінність в інтерпретації результатів антирабічної активності сироваток крові лисиць при використанні тест-систем BioPro Rabies Elisa Ab та Platelia Rabies II BioRad, що виникла в 2018 році в різних лабораторіях, та, на нашу думку, призвела до завищених результатів в оцінці антирабічної 
активності сироваток крові лисиць в певних (східних і центральних) областях в $2018 \mathrm{p}$.

Оцінка ефективності кампаній з пероральної вакцинації диких м'ясоїдних проти сказу шляхом дослідження сироваток крові лисиць в багатьох європейських країнах показала відсоток позитивних проб в межах 40-50\% [5]. Однак, враховуючи те, що кампанії з пероральної вакцинації диких м'ясоїдних проти сказу в Україні в 2018-2020 рр. були проведені тільки один раз в рік, то, на нашу думку, отриманий відсоток позитивних до вірусу сказу сироваток крові лисиць на рівні 24,3 та 18,6\% (в 2019 і 2020 рр. відповідно) є цілком очікуваним та прогнозованим результатом.

\section{Висновки та перспективи подальших досліджень:}

1. Встановлено тенденцію до зменшення превалентності сказу тварин в Україні протягом 2018-2020 років. В 2019 році кількість лабораторно підтверджених випадків сказу була меншою на 479 випадків, або на 25,0\% порівняно з 2018 роком; в 2020 році на 160 випадків менше, або на 11,1\% порівняно з 2019 роком.

2. Виявлено біомаркер тетрациклін в зубах диких м'ясоїдних за 2018-2020 pp. у 14646 зразках із 31001, що становило 47,24\%.

3. Серологічна оцінка ефективності кампаній з пероральної вакцинації диких м'ясоїдних проти сказу виявила 37,7\% позитивних тварин після кампанії 2018 року; 24,3\% позитивних сироваток після кампанії 2019 року та 18,6\% після кампанії 2020 року.

4. Проведена оцінка ефективності кампаній 3 пероральної вакцинації диких м'ясоїдних проти сказу в 2018-2020 роках виявила ефективність цього заходу, однак для досягнення належного результату, який забезпечить переривання епізоотичного ланцюга за рахунок формування необхідного антирабічного популяційного імунітету (не менше 50\%), необхідним $\epsilon$ проведення кампаній двічі на рік - весною та восени.

\section{СПИСОК ЛІТЕРАТУРИ}

1.WHO expert consultation on rabies: third report. / World Health Organization. - Geneva: WHO, 2018. - $195 \mathrm{p}$.

2.Oral immunisation of foxes against rabies. A field study / F. Steck, A. Wandeler, P. Bichsel [et al.] // Zbl. Veterinärmed. - 1982. - Vol. 29. - P. 372-396.

3.Hanlon C.A. Rabies in terrestrial animals / C.A. Hanlon // Rabies; Jackson A.C., Wunner W.H. (Eds). - London: Academic Press, 2007. - P. 201-246.

4.Rabies in Europe - Trends and Developments / C.J. Potzsch, A. Kliemt, D. Kloss [et al.] // First International Conference on Rabies in Europe (Kyiv, 15-18 June, 2005). - OIE, 2005. - P. 59-69. 
5.Oral vaccination of wildlife using a vaccinia-rabies-glycoprotein recombinant virus vaccine (RABORAL V-RG): a global review / J. Maki, A. Guiot, M. Aubert [et al] // Vet Res. 2017. - 48(1):57. https://doi.org/10.1186/s13567-017-0459-9.

6.Оздоровлення території України від сказу - невідкладні завдання науки і практики / В.В. Недосєков, Л.П. Гришок, І.М. Полупан [та ін.] // Ветеринарна медицина України. 2009. - № 2. - C. 12-13.

7.An Analysis of Rabies Incidence and Its Geographic Spread in the Buffer Area Among Orally Vaccinated Wildlife in Ukraine from 2012 to 2016 / I. Polupan, M. Bezymennyi, Y. Gibaliuk [et al.] // Frontiers in Veterinary Science. - 2019. - Vol. 6. - P. 290.

8.Удосконалення системи антирабічних заходів в Україні / I.M. Полупан, Ж.М. Дрожже, Ю.О. Гібалюк [та ін.] // Вісник Дніпропетровського державного аграрноекономічного університету. - 2018. - № (1-2). - С. 149-152.

9.Spatio-temporal use of oral rabies vaccines in fox rabies elimination programmes in Europe / T. Müller, R. Schröder, P. Wysocki [et al.] // PLoS Negl Trop Dis. - 2015. - Vol. 9 $\mathrm{e} 0003953$.

10. Rabies (infection with rabies virus and other lyssaviruses). Manual of Diagnostic Tests and Vaccines for Terrestrial Animals (Mammals, Birds and Bees). - Paris: OIE, 2018. - Access mode: https://www.oie.int/fileadmin/Home/eng/Health_standards/tahm/ 3.01.17_RABIES.pdf.

\section{ОЦЕНКА ЭФФЕКТИВНОСТИ ПЕРОРАЛЬНОЙ ИММУНИЗАЦИИ ДИКИХ ПЛОТОЯДНЫХ ЖИВОТНЫХ ПРОТИВ БЕШЕНСТВА (2018-2020 гг.) / Полупан И.Н., Рудой О.В., Ложкина Е.В., Павлунько В.Г., Купневская М.В., Теплых Н.И., Кравченко А.Л., Гибалюк Ю.О.}

В статье представлены материаль анализа эффективности кампаний пероральной вакцинации диких плотоядных животных против бешенства, которые были проведены в Украине в 2018-2020 г2. Оиенка эффективности кампаний пероральной вакцинации диких плотоядных против бешенства в 2018-2020 роках выявила эффективность этого мероприятия, но для достижения необходимого результата необходимо проведение кампаний дважды в год - весною и осенью.

Исследования показали тенденцию к уменьшению превалентности бешенства животных в Украине в 2018-2020 г2. (в 2019 г. на 25,0\% сравнительно с 2018 г.; в 2020 г. на 11,1\% сравнительно с 2019 г.). Выявлено биомаркер тетрациклин в зубах диких плотоядных животных в 14646 образиах с 31001 исследованных, что составляло 47,24\%. Серологическими исследованиями выявлено 37,7\% позитивных животных после кампании 2018 г.; 24,3\% позитивных сывороток крови после кампании 2019 г. и 18,6\% после кампании 20202.

Ключевые слова: бешенство, эпизоотическая ситуачия, пероральная вакиинация, дикие плотоядные животные, биомаркер тетрациклин, антирабические антитела. 
ASSESSMENT OF THE EFFECTIVENESS OF ORAL IMMUNIZATION OF WILD CARNIVOROUS ANIMALS AGAINST RABIES (2018-2020) / Polupan I.M., Rudoi O.V., Lozhkina O.V., Pavlunko V.G., Kupnevska M.V., Teplykh N.I., Kravchenko A.L., Gibaliuk Y.O.

Introduction. Wild carnivores such as red foxes play an important role in maintaining the existence and functioning of hotspots of rabies. The main method of control of rabies in the wild is the oral vaccination of wild animals carnivores against rabies.

The goal of the work. Evaluation of the effectiveness of oral vaccination of wild carnivores against rabies conducted in Ukraine in 2018-2020.

Materials and methods of research. Pathological material (brain) was tested in regional laboratories of veterinary medicine by FAT. The presence of the biomarker tetracyclin was determined under a fluorescent microscope. Rabies antibody activity in blood serums were tested by ELISA.

Results of research and discussion. There is a tendency to reduce the prevalence of animal rabies in Ukraine during 2018-2020. In 2019, the number of laboratory-confirmed cases of rabies was lower by 479 cases, or $25.0 \%$ compared to 2018; in 2020 by 160 cases less or $11.1 \%$ compared to 2019.

The tetracycline biomarker was detected in the teeth of wild carnivores in 2018-2020 in 14,646 samples of 31,001, which was 47.24\%. In 2018, the percentage of positive samples was $46.7 \%$, in $2019-50.1 \%$, and in $2020-44.0 \%$.

Serological evaluation of the effectiveness of oral vaccination of wild carnivores against rabies revealed $37.7 \%$ of positive animals after the 2018 campaign; $24.3 \%$ of positive sera after the 2019 campaign and $18.6 \%$ after the 2020 campaign.

Conclusions and prospects for further research. Evaluation of the effectiveness of campaigns of oral vaccination of wild carnivores against rabies in 2018-2020 in Ukraine demonstrated the effectiveness of this measure, but to achieve the desired result, which will interrupt of the epizootic chain by forming of the high rabies population immunity (at least 50\%), it is necessary campaigns of oral vaccination of wild carnivores against rabies twice a year - in spring and autumn.

Keywords: rabies, epizootic situation, oral vaccination, wild carnivores, tetracycline biomarker, rabies antibodies.

\section{REFERENCES}

1. WHO (2018). WHO Expert Consultation on Rabies. Geneva: WHO.

2. Steck, F., Wandeler, A., Bichsel, P., Capt, S., \& Schneider, L. (1982). Oral immunisation of foxes against rabies. A field study. Zbl. Veterinärmed, 29, 372-396.

3. Hanlon, C.A. (2007). Rabies in terrestrial animals. Rabies. A.C. Jackson, W.H. Wunner (Eds.). Academic Press.

4. Pötzsch, C.J., Kliemt, A., Klöss, D., Schröder, R., \& Müller, W. (2005). Rabies in Europe - Trends and Developments. First International Conference on Rabies in Europe. (pp. 5969). Paris: OIE.

5. Maki, J., Guiot, A.L., Aubert, M., Brochier, B., Cliquet, F., Hanlon, C.A., et al. (2017). Oral vaccination of wildlife using a vaccinia-rabies-glycoprotein recombinant virus vaccine (RABORAL V-RG): a global review. Vet Res., 48:57. https://doi.org/10.1186/s13567-017-0459-9.

6. Nedosekov, V., Grishok, L., Polupan, I., \& Ivanov, M. (2009). Ozdorovlenyy territorii Ukrainy vid skazy - nevidkladne zavdannay nauki i praktyky [Sanation of the territory of Ukraine 
from rabies is an urgent task of science and practice]. Veterinarna medycina Ukrainy - Veterinary medicine of Ukraine, 2, 12-15 [in Ukrainian].

7. Polupan, I., Bezymennyi, M., Gibaliuk, Y., Drozhzhe, Z., Rudoi, O., Ukhovskyi, V., Nedosekov, V., \& De Nardi, M. (2019). An analysis of rabies incidence and its geographic spread in the buffer area among orally vaccinated wildlife in Ukraine from 2012 to 2016. Frontiers in Veterinary Science, 6, 290. https://doi.org/10.3389/fvets.2019.00290.

8. Polupan, I., Drozhzhe, Z., Gibaliuk, Y., \& Sharai, Ia. (2018). Udoskonalennya systemy antyrabichnykh zakhodiv v Ukrayini [Improving of the system of rabies measures in Ukraine]. Visnyk Dnipropetrovskoho derzhavnoho ahrarno-ekonomichnoho universytetu - Bulletin of Dnipropetrovsk State Agrarian and Economic University, 1-2, 149-152 [in Ukrainian].

9. Müller, T.F., Schröder, R., Wysocki, P., Mettenleiter, T.C., \& Freuling, C.M. (2015). Spatio-temporal use of oral rabies vaccines in fox rabies elimination programmes in Europe. PLoS Negl Trop Dis., 9:e0003953. https://doi.org/10.1371/journal.pntd.0003953.

10.Rabies (infection with rabies virus and other lyssaviruses). Manual of Diagnostic Tests and Vaccines for Terrestrial Animals (Mammals, Birds and Bees). (2018). Paris: OIE. Retrieved from https://www.oie.int/fileadmin/Home/eng/Health_standards/tahm/3.01.17_RABIES.pdf. 